\title{
SEXUAL RECEPTIVITY AND OESTRUS IN THE WHITE-TOOTHED SHREW, CROCIDURA RUSSULA MONACHA
}

\author{
S. HELLWING \\ Department of Zoology, The George S. Wise Center for Life Sciences, \\ Tel Aviv University, Tel Aviv, Israel
}

(Received 12th February 1975)

\begin{abstract}
Summary. In common white-toothed shrews, the vaginal smear was an inadequate indicator of receptivity. Nucleated epithelial cells usually predominated and most matings took place when the smear was of this type. Cornified cells in the smear were infrequent. Mating tests showed that virgin females 2 to 4 months old, were unreceptive for extended periods. Willingness to mate increased gradually with the age of the female. Females were receptive throughout pregnancy, suggesting a continuous secretion of oestrogen during gestation. There was a postpartum oestrus whether or not the young of the litter were being suckled, and an oestrus at the end of lactation. During mid-lactation, females were in a state of low receptivity, whether or not they were suckling.
\end{abstract}

\section{INTRODUCTION}

Recurrent periods of oestrus, characteristic of many seasonally breeding mammals, have not been so far demonstrated in any shrew of the subfamily Crocidurinae, the largest group of the family Soricidae. Dryden (1969) reported that in the musk-shrew, Suncus murinus, from Guam, there was no apparent cycle of ovarian activity and non-pregnant shrews remained receptive for as long as 3 weeks. Naik \& Dominic (1970), who worked on the same species in India, found that the female was capable of remaining in a constant state of receptivity for a period of 6 weeks. A post-partum oestrus has been reported for Crocidura leucodon (Frank, 1953), C. russula (Vogel, 1970), C. suaveolens cassiteridum (Rood, 1965), Suncus murinus (Dryden, 1969; Naik \& Dominic, 1970), and S. etruscus (Vogel, 1970; Fons, 1973). Copulations during lactation were observed in captive $S$. murinus by Dryden (1970).

In the common white-toothed shrew (Crocidura russula monacha) ovulation is induced by mating, pregnancy lasts for 28 to 29 days, and lactation extends for 21 to 22 days (Hellwing, 1973). The present study was undertaken to examine the sexual receptivity and oestrus in this shrew which is distributed in many parts of the Eastern Mediterranean region.

\section{MATERIALS AND METHODS}

A breeding colony of the white-toothed shrew is being maintained at the 
Research Zoo of the Tel Aviv University. Husbandry techniques and some data on the reproductive biology have been described earlier (Hellwing, 1971, 1973).

\section{Vaginal smears}

Smears were taken daily by flushing the vagina with saline from an eyedropper. They were air-dried and stained with Shorr's stain. Some females were introduced, after taking the smear, to virile males to test receptivity, and after copulation was observed a second vaginal smear was taken. The abundance of nucleated epithelial cells, cornified cells and leucocytes was estimated.

\section{Mating tests}

Sexual receptivity was tested in 34 virgin females, 34 lactating females and 16 post-partum but non-lactating females. They were removed daily from their cages and individually introduced into a mating cage $(43 \times 30 \times 21 \mathrm{~cm})$ with a fertile male for $1 \mathrm{hr}$. Shrews usually do not fight when introduced suddenly to a strange male. A female was scored as receptive when mounting and copulating thrusts were observed. Copulations were allowed to go to completion to guarantee ovulation and fertilization. If the female was unreceptive to the first male, she was, after $1 \mathrm{hr}$, introduced to a second male. For some females, up to six males were tested. The mating test was usually performed at 12.00 hours, the observer being in full view of the animals at a distance of $0.5 \mathrm{~m}$ from the mating cage. The females were returned to their cages at the end of the tests. The cages were later inspected daily for the presence of litters. Some females were killed during pregnancy in order to obtain histological evidence about ovulation and fertilization.

\section{Analysis of colony records}

Information about receptivity and fertility during lactation was obtained from the frequency distribution of litter intervals in permanently paired breeding shrews.

\section{RESULTS}

In their sexual interactions, the shrews displayed a variety of stereotyped motor acts which appeared in a certain succession, and a basic repertoire of eleven patterns was found and will be reported on elsewhere. The most important stages were the perineal investigation, the precopulatory dance and autogrooming by the male after each intromission. Receptivity occurred sooner in the presence of an experienced adult male, and male aggression played an important role in copulation success.

\section{Vaginal smear}

The contents of the smear were found to be a poor guide to receptivity in 43 of the shrews whose smears were analysed in detail. There was no regular pattern of vaginal cyclicity: nucleated epithelial cells predominated every day and very few cornified cells were seen. Most matings took place when there was a predominantly nucleated smear. 
Mating tests

Willingness of virgin females to mate increased with age. Isolated females were extremely aggressive towards males when 2 to 4 months of age, but when 5 to 9 months old they were more prepared to copulate. Only 5/20 2- to 4month-old females mated at the first introduction, but all fourteen older females did so. Willingness to mate increased if the young females were exposed to males for long periods: four females which were permanently caged after weaning with males of the same age gave birth for the first time when 75 days old, 2 months earlier than four other females of the same age, but separately caged and introduced to active males for $1 \mathrm{hr}$ daily during a period of at least 2 months.

\section{Pregnant females}

During pregnancy, whether or not there was a concurrent lactation, females were prepared to copulate. Twenty-three pregnant females, eleven lactating and twelve non-lactating (the young were removed on Day 1 of lactation), were tested simultaneously for receptivity on various days of pregnancy. All the females were receptive throughout pregnancy and normal embryos were found in the uterus or were born at term (Table 1).

\section{Parous females}

After parturition, the shrews were receptive, regardless of whether they were lactating, but the proportion that mated varied with time post partum (Table 2).

After a peak of receptivity immediately after parturition, there was less activity until Days 15 to 25 post partum. Shrews which did not become pregnant at the post-partum oestrus, conceived towards the end of lactation. The young of 31 lactating and permanently paired females were weaned on Day 22 after birth. The females littered again between Days 46 and 56 after the first litter and $45 \%$ did so on Day 52. Since the mean gestation length is 29 days, these females had conceived the day after removal of the young.

These results demonstrating post-partum and post-lactational high fertility with an intervening period of low fertility were corroborated by the analysis of colony records for the years $1970-73$, when the young were customarily removed on Day 22 after birth (Group A). From Text-fig. 1(a) it is clear that the distribution of births in the colony was not uniform. There was a major peak of births at about 28 to 29 days post partum, the modal gestation period, and a second peak between Days 50 and 53 . About $53 \%$ of the colony females mated within the first 2 days after parturition and there was no suppression of oestrus at the onset of lactation. The clear gap in the occurrence of litters between Days 38 to 42 post partum seemed to be the result of a drop in receptivity during midlactation ( 7 to 10 days post partum) when no conception took place.

As in females whose young were weaned at Day 22, most females whose young were removed on Day 16 (Group B) mated and conceived soon after parturition and about $70 \%$ of the litters were born between Days 24 to 33 , but about $20 \%$ occurred between Days 34 to 47 post partum (Text-fig. Ib), in contrast to the $4.6 \%$ for Group A females at this time ( $F=449, P<0.001$; equality test of two percentages: Sokal \& Rohlf, 1969). This suggests that in Group B 


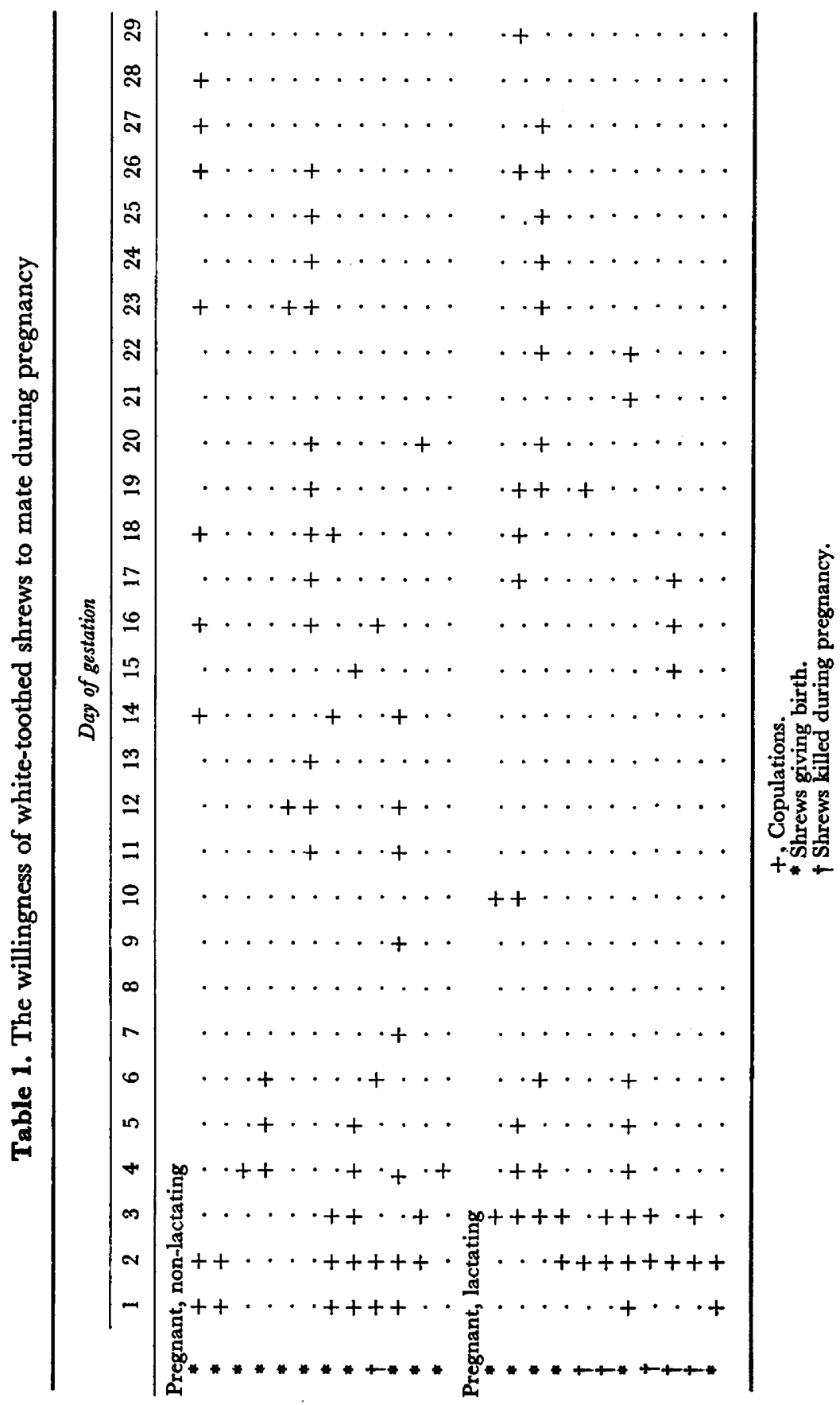


Table 2. Behaviour of female white-toothed shrews at various times after parturition

\begin{tabular}{|c|c|c|c|c|c|c|}
\hline \multirow{2}{*}{$\begin{array}{l}\text { Time after } \\
\text { parturition } \\
(\text { days })\end{array}$} & \multirow[b]{2}{*}{$\begin{array}{l}\text { No. of females } \\
\text { tested }\end{array}$} & \multicolumn{2}{|c|}{$\begin{array}{c}\text { Females } \\
\text { mating }\end{array}$} & \multirow{2}{*}{$\begin{array}{c}\text { No. of } \\
\text { pregnancies }\end{array}$} & \multicolumn{2}{|c|}{ Behaviour } \\
\hline & & No. & $\%$ & & $\begin{array}{l}\text { Sitting } \\
\text { together }\end{array}$ & Fighting \\
\hline $\begin{array}{c}1-2 \\
3-4 \\
5-6 \\
7-8 \\
9-10 \\
11-12 \\
13-14 \\
15-16 \\
17-18 \\
19-20 \\
21-22 \\
23-24 \\
25-26 \\
27-28\end{array}$ & $\begin{array}{l}77 \\
50 \\
50 \\
45 \\
44 \\
48 \\
40 \\
45 \\
36 \\
39 \\
29 \\
28 \\
27\end{array}$ & $\begin{array}{r}43 \\
27 \\
16 \\
7 \\
5 \\
9 \\
5 \\
10 \\
11 \\
15 \\
8 \\
13 \\
11\end{array}$ & $\left.\begin{array}{l}55 \cdot 8 \\
54.0 \\
32 \cdot 0 \\
15.5 \\
11.3 \\
18.7 \\
12.5 \\
22.2 \\
30 \cdot 5 \\
40.5 \\
27.5 \\
46.4 \\
40.7\end{array}\right\}$ & $\begin{array}{r}18 \\
5 \\
0 \\
0 \\
0 \\
0\end{array}$ & $\begin{array}{c}++ \\
++ \\
+ \\
+ \text { to }+++ \\
++ \\
+ \\
+ \\
++ \\
+ \\
+ \\
+ \\
+ \\
+ \\
+\end{array}$ & $\begin{array}{r}+ \\
++ \\
+++ \\
+++ \\
+++ \\
+++ \\
+++ \\
+++ \\
+++ \\
++ \\
+ \\
+ \\
++ \\
++\end{array}$ \\
\hline
\end{tabular}

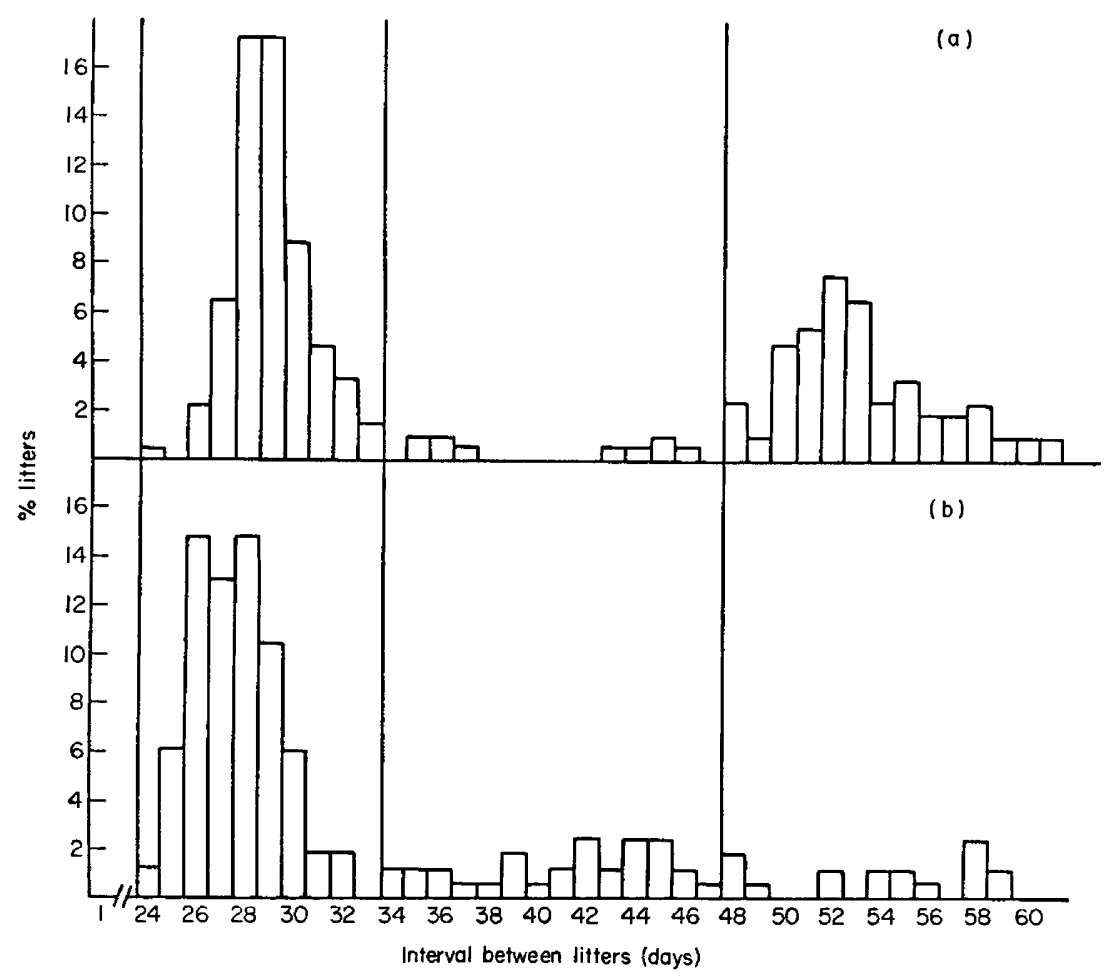

Text-FIG. 1. Frequency distribution of intervals between the first and second litters of lactating white-toothed shrews when the young were weaned (a) on Day 22 (213 litters), and (b) on Day 16 (162 litters) after birth. The vertical lines show the period when few litters are born, corresponding to the drop in receptivity of females in mid-lactation. Day 1 is the day of birth of the first litter. 
females the ability to conceive earlier increased when lactation was interrupted. Removal of young at Day 20 for 140 litters also suggested a tendency for earlier parturitions, but the numbers of litters for the interval from Days 34 to 47 post partum $(7.8 \%)$ was not significantly different.

A similar ability to mate and conceive after nursing ceased suddenly was found in shrews that lost their young during the lactation period. While $67.5 \%$ littered again at 27 to 32 days post partum, $32.5 \%$ of the shrews whose young died 8 to 15 days after birth littered 34 to 43 days after the first parturition and hence had conceived soon after loss of the young (Table 3 ).

\section{DISGUSSION}

Some of the results obtained in this species of shrew confirm those published by Dryden $(1969,1970)$ for S. murinus (Crocidurinae) and by Breed (1969) for Microtus agrestis (Microtinae), both small mammals with induced ovulation.

As in the white-toothed shrew, the vaginal smear in the field vole and muskshrew does not indicate an ovulatory cycle. Some $S$. murinus females copulated when the smear appeared equivalent to that of a pro-oestrous or oestrous smear in a mouse and other females mated when exhibiting what would be a dioestrous smear. Breed (1969) reports that in Microtus agrestis most matings took place when there was a predominantly nucleated epithelial smear. Warkentin \& Conaway (1969), who attempted to characterize the oestrous cycle in Tupaia chinensis by the vaginal smear method, found that a female with a smear of $100 \%$ leucocytes mated twice. In Meriones unguiculatus no regular oestrous cycle could be found using vaginal smears (Marston \& Chang, 1965). The scarcity of cornified cells in the vaginal epithelium of Crocidura russula may indicate a general low oestrogen level or a low sensitivity of the vaginal epithelium to oestrogen. Naik \& Dominic (1970), after injecting large doses of oestrogen to $S$. murinus, found no complete cornification of the vaginal epithelium. It is therefore possible that lack of cornification of the vaginal epithelium is a characteristic of the Crocidurinae as a whole.

As in Crocidura, non-pregnant musk-shrews (S. murinus) remain unreceptive for extended periods and the presence and aggression of the male play an important role in copulation success. There was also an indication that the presence of an adult male may hasten sexual maturity and sexual receptivity in young female $C$. russula. There is a fertile post-partum oestrus in $C$. russula and $S$. murinus, and in both species there is the possibility of a continuous succession of pregnancies during the year.

Since female $C$. russula do not always conceive immediately after parturition and will usually not do so during mid-lactation, it is possible that intense suckling during mid-lactation inhibits release of gonadotrophins and hence a depression of the ovulation response to mating. A similar suppression of oestrus due to lactation was found by Dryden (1970) for S. murinus; $67 \%$ of the tested animals gave birth to young which had been conceived after nursing was interrupted, often in advanced lactation. Experimental interruption of lactation in captive $C$. russula strongly suggests the ability of the shrew to compensate 


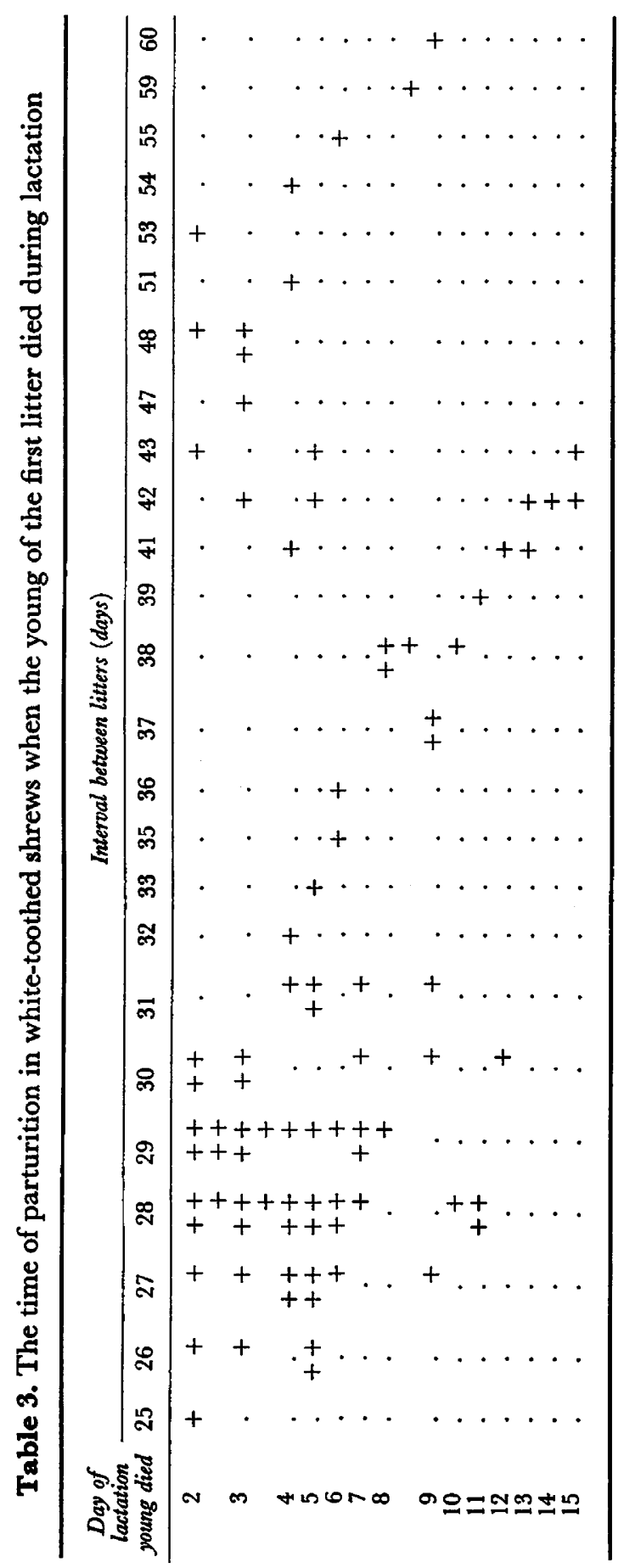


for the loss of their young by re-impregnation and conception immediately after the suckling stimulus ceases.

Since there is some variation when lactating and non-lactating $C$. russula females will mate after parturition (see Table 1), other factors besides suckling must be influencing receptivity in the post-partum period. Foxcroft \& Hasnain (1973) have suggested such a possibility in the domestic rabbit. Although suckling reduced the ovulation response to mating in large albino does, an underlying effect of time related to mating and fertility after parturition was found. They concluded that the effect of suckling may accentuate only other physiological changes with time. In Microtus agrestis (Breed, 1969), however, suckling or time after parturition does not inhibit coitus and fertilization. Mating tests carried out between Days 2 to 13 of lactation showed that coitus occurred on all days and $59 \%$ of the matings resulted in pregnancy.

Lactating and non-lactating pregnant $C$. russula mate during the 1st, 3rd and 4th week of the 28-day gestation period. A similar pattern of receptivity following conception occurs in S. murinus (Dryden, 1969) and Blarina brevicauda (Pearson, 1944), although in these species most copulations occur before or about the time the embryos reached the uterus (Day 7). Naik \& Dominic (1970), however, did not observe any mating activity during pregnancy in $S$. murinus from India. Long periods of receptivity during pregnancy have been found also in Tupaia montana (Sorenson \& Conaway, 1968). In spite of the occurrence of multiple copulations during pregnancy in C. russula, superovulation or superfetation did not occur since there were no fresh corpora lutea and all the embryos were at the same stage of development. Of the shrews so far studied, most experience an oestrus soon after parturition in natural conditions and in captivity, although no post-partum oestrus seems to occur in Blarina brevicauda (Pearson, 1944). According to Conaway (1971), the mechanism of the post-partum oestrus increases productivity, and this seems to be its most important biological function in the reproductive cycle of shrews which have a relatively short life-span.

\section{ACKNOWLEDGMENTS}

The author is grateful to Dr J. R. Clarke (University of Oxford) for his helpful criticism of the manuscript, to $\mathrm{Mr} \mathrm{S}$. Schäfer for drawing the figure, to $\mathrm{Mr} \mathrm{O}$. Ben-Menachem for keeping the breeding-book of the shrew colony and to Mrs L. Gliksman for typing the manuscript.

\section{REFERENCES}

BreED, W.G. (1969) Oestrus and ovarian histology in the lactating vole (Microtus agrestis). F. Reprod. Fert. 18, 33-42.

Conaway, C.H. (1971) Ecological adaptations and mammalian reproduction. Biol. Reprod. 4, 239-247.

DRYDEN, G.L. (1969) Reproduction in Suncus murinus. F. Reprod. Fert., Suppl. 6, 377-396.

Dryden, G.L. (1970) Post-parturitional conception in captive musk shrews, Suncus murinus. F. Reprod. Fert. 23, 493-495.

Fons, R. (1973) Modalités de la reproduction et developement postnatal en captivité chez Suncus etruscus (Savi, 1822). Mammalia 37, 288-324.

Foxcroft, G.R. \& Hasnain, H. (1973) Effects of suckling and time to mating after parturition on reproduction in the domestic rabbit. $\mathcal{F}$. Reprod. Fert. 33, 367-377. 
Frank, F. (1953) Beiträge zur Biologie-insbesondere Paarungsbiologie der Feldspitzmaus (Crocidura leucodon, Herm.) Bonn. zool. Beitr. 4, 187-194.

Hellwing, S. (1971). Maintenance and reproduction in the white toothed shrew, Crocidura russula monacha, Thomas, in captivity. Z. Saugetierk. 36, 103-113.

Hellwing, S. (1973) Husbandry and breeding of white-toothed shrews (Crocidurinae) in the Research Zoo of the Tel Aviv University. Int. Zoo $r b$. 13, 127-134.

Marston, J.H. \& Chang, M.C. (1965) The breeding, management and reproductive physiology of the Mongolian gerbil (Meriones unguiculatus). Lab. Anim. Care 15, 34-48.

NAIK, D.R. \& Dominic, C.J. (1970) Observations on the vaginal cell types, sexual receptivity and on the mating behaviour of the musk shrew Suncus murinus L. (Insectivora). Indian Biol. 2, 66-74.

Pearson, O.P. (1944) Reproduction in the shrew (Blarina brevicauda Say). Am. F. Anat. 75, 39-93.

Rood, J.P. (1965) Observations on population structure, reproduction and molt of the Scilly shrew. F. Mammal. 46, 426-433.

Sokal, R.R. \& Rohlf, F.J. (1969) Biometry. W. H. Freeman \& Co., San Francisco.

Sorenson, M.W. \& ConAWAY, C.H. (1968) The social and reproductive behavior of Tupaia montana in captivity. F. Mammal. 49, 502-512.

Vogel, P. (1970) Biologische Beobachtungen an Etruskerspitzmäusen (Suncus etruscus, Savi 1832). Z. Saugetierk. 35, 173-185.

Warkentin, M.J. \& Conaway, C.H. (1969) Vaginal smears in the tree shrew (Tupaia chinensis). $\mathcal{F}$. Mammal. 50, 817-818. 